\title{
Climate-induced community relocations: using integrated social-ecological assessments to foster adaptation and resilience
}

\author{
$\underline{\text { Robin Bronen }}^{1,2}$
}

\begin{abstract}
Extreme weather events coupled with sea level rise and erosion will cause coastal and riverine areas where people live and maintain livelihoods to disappear permanently. Adaptation to these environmental changes, including the permanent relocation of millions of people, requires new governance tools. In the USA, local governments, often with state-level and national-level support, will be primarily responsible for protecting residents from climate-change impacts and implementing policies needed to protect their welfare. Government agencies have a variety of tools to facilitate protection in place and managed coastal retreat but have very limited tools to facilitate community relocation. In addition, no institutional mechanism currently exists to determine whether and when preventive relocation needs to occur to protect people from climate change impacts. Based on research involving four Alaska Native communities threatened by climate-induced environmental impacts, I propose the design and implementation of an adaptive governance framework to respond to the need to relocate populations. In this context, adaptive governance means the ability of institutions to dynamically respond to climate change impacts. A component of this adaptive governance framework is a social-ecological monitoring and assessment tool that can facilitate collaborative knowledge production by community residents and governance institutions to guide sustainable adaptation strategies and determine whether and when relocation needs to occur. The framework, including the monitoring and assessment tool, has not been systematically tested. However, the potential use of this tool is discussed by drawing on empirical examples of Alaskan communities faced with accelerating rates of erosion.
\end{abstract}

Key Words: adaptation; climate change; coastal retreat; community relocation; social-ecological monitoring and assessment

\section{INTRODUCTION}

Extreme weather events combined with accelerating biophysical change such as erosion threaten the lives and livelihoods of human populations who reside in coastal and riverine communities worldwide. Sea level rise is accelerating, reached record highs in 2012, and is expected to worsen over the next century because of increased rates of ice sheet mass loss from Antarctica and Greenland and thermal expansion (Nicholls and Cazenave 2010, Joughlin et al. 2014). Sea level rise contributes to flooding, sea surges, erosion, and salinization of land and water (IPCC 2012). These climate-induced environmental changes will cause land to disappear permanently. People will lose their homes and connection with heritage and cultural and spiritual ties to the land (Grannis 2011).

Fiscally, the cumulative effect of frequent extreme weather events is challenging the capacity of governance institutions at local, regional, and national levels to prepare for and respond to these events (IPCC 2012). Governments are spending large amounts of money on disaster preparation, insurance payouts, and rebuilding damaged or destroyed infrastructure to protect people and the infrastructure on which they depend (Nichols and Bruch 2008). In addition, a valuable government tax base will no longer exist as coastal land becomes increasingly marginal for human habitation (Grannis 2011). Economic activities, including livelihoods, will be disrupted. Sea walls and storm surge barriers may not be able to provide protection (Bronen 2011).

Currently, no governance framework exists in the United States or elsewhere to evaluate climate change impacts and determine when people can no longer be protected in place (Bronen 2011, Ferris 2012). This lack of a governance framework hampers the ability of local, regional, and national government agencies to respond. If climate-induced environmental change renders the places where people live uninhabitable and causes land to disappear, new governance institutions need to be designed to determine whether people can be protected in place or require relocation (Bronen 2011, Bronen and Chapin 2013).

Relocation is “a process whereby a community's housing and public infrastructure are rebuilt in another location" (Jha 2010:77). In addition, relocation can also include rebuilding livelihoods and social networks. Preventive relocations, which occur prior to a disaster, can be a critical disaster risk reduction tool that can save lives and offer long-term protection. No institutional mechanism exists to determine when a preventive relocation should occur, who should make this decision, or how the decision should be made. International law requires nation state governments to protect vulnerable populations from climate-induced environmental change (ICISS 2001). The duty to protect is inherent in the concept of sovereignty and implies that the nation state government has the primary responsibility for the protection of populations within its jurisdiction (ICISS 2001). In 2008, the European Court on Human Rights found in the Budayeva decision that the failure of state authorities to implement preventive land-use planning and emergency evacuation policies in the hazardous area of a Caucasus mountain town caused the death of eight people (Kälin 2011). The Court ordered the State to pay compensation to the family members of the survivors (Kälin 2011).

The government responsibility to protect people through the implementation of preventive relocations may require relocation against people's will (Ferris 2012). However, governmentmandated relocations have been uniformly disastrous for the people relocated. Development projects, particularly dams, have displaced approximately 280-300 million people between 1990 and 2010 (Ferris 2012). Governments have also forcibly relocated 
people for geopolitical motives (Tester and Kulchyski 1994). During World War II, the U.S. government forcibly relocated Alaska Natives living on the Aleutian Islands, theoretically to protect them from the Japanese (Mobley 2012). These government-mandated relocations weaken social, cultural, and political institutions, disrupt subsistence and economic systems, and affect the culture and traditional kinship ties within a community (Jha 2010). In Alaska, the forcible relocation of the Aleuts caused the death of approximately $10 \%$ of the relocated population (Mobley 2012).

Currently, most environment-related relocations mandated by government agencies occur in the aftermath of an extreme environmental event or when it is imminently going to occur (Correa 2011). Government decisions to create no-build zones in the aftermath of an extreme weather event can create a de facto relocation process to prevent future vulnerability (Thomas 2014). However, extreme weather events, which cause mass population displacement, may not be an appropriate indicator to evaluate whether people should be relocated. Without scientific evidence to prove that future extreme weather events will threaten the lives and livelihoods of residents at the same location, ad hoc no-build zones could be considered forcible evictions and violate people's human rights (Thomas 2014). In addition, in the aftermath of an extreme weather event, most people want to return home and will do so unless the land on which they lived no longer exists (Raleigh and Jordan 2010).

To address both the severe consequences of governmentmandated relocations and the lack of a methodology to assess climate change risk in relation to the ability of people to remain where they currently live, I propose the design of an adaptive governance relocation framework. Here, I explore one component of such a framework, the design of a social-ecological monitoring and assessment tool. An adaptive governance framework means that governance institutions can respond dynamically to environmental changes and can shift their efforts from protection in place to managed retreat and community relocation (Bronen 2011, Bronen and Chapin 2013). A community-based socialecological assessment tool that can engage community residents in a collaborative decision-making process with government representatives to determine whether and when to relocate may avoid or minimize the harmful effects of government-mandated relocations.

The proposed design of this community-based integrated socialecological monitoring and assessment tool is founded on the monitoring and assessment done by three Alaska Native communities: Shishmaref, Kivalina, and Newtok. Each of these communities began documenting the effects of accelerating rates of erosion, caused by the combination of decreased arctic sea ice, thawing permafrost, and repeated extreme weather events, on the health of community residents and on community infrastructure in the 1980s (GAO 2003, 2009). This monitoring and assessment, although intermittent due to limited funding, garnered government technical assistance and also provided the basis upon which community residents decided that the relocation of their entire community was the only long-term adaptation strategy that could protect them (Bronen and Chapin 2013). In Newtok, Alaska, this community-led documentation of erosion was instrumental to the creation of the Newtok Planning Group, an interdisciplinary working group comprising governmental and nongovernmental agency representatives dedicated to Newtok's relocation and led by the Newtok Traditional Council (Bronen 2011). I also discuss the climate-induced environmental impacts on the Alaska Native village of Quinhagak, USA, and illustrate the way a community-based social-ecological assessment tool can assist the community to develop sustainable adaptation strategies.

\section{METHODS}

Case study analysis of the communities of Shishmaref, Newtok, Kivalina, and Quinhagak, Alaska, USA, was the primary method used to understand the environmental impacts on each community and the governance process to determine how to protect community residents (Esterberg 2002). Data-gathering tools included surveys, interviews, and the study of organizational documents of the Alaska Sub-cabinet on Climate Change Immediate Action Workgroup. Archival document review included review of erosion assessments conducted by the U.S. Army Corps of Engineers, hazard impact assessments, community relocation reports, and federal government relocation, erosion, and climate-change reports. In addition, data gathering included observation at approximately 50 intergovernmental meetings between 2007 and 2012, including meetings of the Newtok Planning Group and the Sub-cabinet on Climate Change Immediate Action Workgroup, where tribal, state, and federal government representatives discussed relocation and multi-level government agency coordination to develop a relocation institutional framework.

\section{GOVERNANCE INSTITUTIONS TO PROTECT IN PLACE}

U.S. federal and state government agencies have a variety of tools to facilitate protection in place and managed retreat from vulnerable coastal and riverine areas, but have very limited tools to facilitate a community-wide relocation. Significant limitations prevent governments from responding effectively and dynamically to climate-induced environmental changes. Here, I outline the current governance mechanisms to control flooding and erosion to protect people where they live. It is important to understand these mechanisms, which have created the expectation that people can be protected in place, to determine the appropriate governance tools for deciding whether and when a preventive relocation needs to occur.

Traditionally, governments and property owners have protected coastal and river development from flooding and erosion using engineered structures such as sea walls (Lewis 2012). Although these solutions have been problematic because they are expensive to build and maintain, they increase flooding and erosion on neighboring properties, and they encourage development of vulnerable areas, they have been the primary response to erosion and flooding (Grannis 2011, Lewis 2012). Governments have also used building codes to maximize the capacity of infrastructure to withstand flooding and provide an additional mechanism to protect in place.

Post-disaster relief also emphasizes rebuilding houses, reconstructing infrastructure, and rehabilitating livelihoods where the disaster occurred to restore these places to a pre-disaster reality (Bronen 2011). Following a disaster, the common response of people is to relocate close to where they have been displaced, with approximately $30 \%$ of the affected population moving away, 
and with $>90 \%$ of those people returning at some later stage (Raleigh and Jordan 2010). As a consequence, in the aftermath of a disaster, decision makers face significant difficulty implementing measures that restrict the ability of people to return to the places where they lived. In Alabama, USA, hurricanes have destroyed dwellings and infrastructure on Dauphin Island 10 times in the past 40 years, most recently in 2005 by Hurricane Katrina. Since 1979, Dauphin Island has received \$80 million (USD) in federal funding ( $>\$ 60,000$ per resident), plus an additional $\$ 72$ million in federal flood insurance payouts to rebuild the community (Siders 2013). Dauphin Island residents paid $\$ 9.3$ million in insurance premiums to offset these costs (Siders 2013).

Managed retreat is another government mechanism that can protect people from extreme weather events, erosion, and flooding. Land-use restrictions include setbacks and acquisition programs. Setbacks are building restrictions that establish a distance from a boundary line, often the tide line in waterfront areas, where landowners are prohibited from building structures (Grannis 2011). Acquisition programs, where property owners voluntarily decide to be bought out by the government, offer another mechanism to orchestrate a managed retreat. With this program, state or local government offers to buy, with public funds, property vulnerable to hazards (Lewis 2012). Acquisition programs normally occur on a household level where individual property owners make the decision to participate in the program. The U.S. Federal Emergency Management Agency (FEMA) discourages using this program to relocate communities in their entirety, although a few communities have chosen to do so (Bronen and Chapin 2013).

Government's ability to use proactive managed retreat to protect people will depend on people understanding that they live in vulnerable locations. Acquisition programs are voluntary, and government decisions that affect property rights have legal implications. Property owners can use the law to support their desire to remain protected in place and prevent the government from implementing land-use and building restrictions (Siders 2013). As a consequence, these legal standards can delay the ability of government actors to move people proactively from vulnerable coastal and riverine areas.

Climate-induced environmental change presents a completely different scenario than that contemplated by current laws designed to respond to extreme weather events, erosion, and flooding. While government agencies may be able to use land-use restrictions and acquisition programs as a way of managing coastal retreat, these tools will be insufficient to respond to the complexity of mass population displacement and the need to rebuild livelihoods, homes, and community infrastructure in new locations.

The current governance tools to protect people and infrastructure may only offer short-term protection because of increased rates of sea level rise, and the consequent increased intensity of storm surges, flooding, and erosion. Sea level rise will cause land to disappear permanently. Decision makers will need to balance many trade-offs when deciding whether to protect people in situ, such as the degree of threat to people and property, the cost to build erosion or flood control infrastructure, the value of threatened property or infrastructure and long-term maintenance costs, and the physical conditions of the land (Grannis 2011). Similarly, setbacks will be less effective over the long term as sea level rise inundates broad areas of low-lying land (Grannis 2011). In the context of a rapidly changing environment, the ongoing effort to protect people in place may lead to recovering in ways that re-create or even increase existing vulnerabilities and preclude longer term planning and policy changes for enhancing resilience and adaptation (Grannis 2011, Lewis 2012). For this reason, it is critical to understand the rates of environmental change to plan for a preventive relocation prior to the land's disappearance.

\section{ALASKA}

In Alaska, the combination of decreased Arctic sea ice extent, thawing permafrost, and repeated extreme weather events is causing several Alaska Native communities to choose to relocate. In Shishmaref, Kivalina, and Newtok, local and tribal governments decided that relocation is the only long-term sustainable adaptation strategy after documenting the environmental changes occurring within each community over several decades (Bronen and Chapin 2013). The governance challenges to relocate these communities have been enormous. Despite the U.S. Government Accountability Office finding that at least 12 Alaskan communities were seeking relocation in 2009, no community has yet relocated (Fig. 1; Bronen and Chapin 2013).

Equally challenging has been the process to determine when protection in place is no longer possible and community relocation is required. Erosion is the principal threat to the habitability of Alaska Native villages (USACE 2006, 2009). With diminishing Arctic sea ice extent to protect coastal communities, waves and storm surges are accelerating erosion (GAO 2003, 2009). The institutional mechanisms to control erosion have not been able to provide long-term protection to some communities, despite the expenditure of millions of dollars. In Kivalina, for example, federal and state government agencies spent approximately $\$ 15.5$ million between 2006 and 2009 to protect the community with engineered seawall structures with a lifespan of 10-15 years (Bronen and Chapin 2013).

The Alaska Legislature established the Alaska Climate Change Impact Mitigation Program (ACCIMP) in 2008 to address the immediate planning needs of communities imminently threatened by climate-induced environmental change (Bronen and Chapin 2013). Through this program, the City of Quinhagak received funding to complete a hazard impact assessment (HIA), and completed a hazard mitigation plan in January 2012 (City of Quinhagak Mitigation Planning Team 2012). The HIA process demonstrates the complexity of the issues facing communities threatened by climate-induced environmental change and the need to design and implement a community-based monitoring and assessment process.

\section{QUINHAGAK}

Quinhagak is surrounded by shallow lakes and wetlands. The community is only accessible by air or water and is home to approximately 700 primarily Yup'ik Eskimo residents whose lifestyle revolves around subsistence food gathering (City of Quinhagak Mitigation Planning Team 2012, Powtec 2012). Erosion, river flooding, coastal storm surge, and thawing permafrost threaten residential dwellings, critical community 
Fig. 1. Twelve Alaska Native villages that are seeking to relocate.

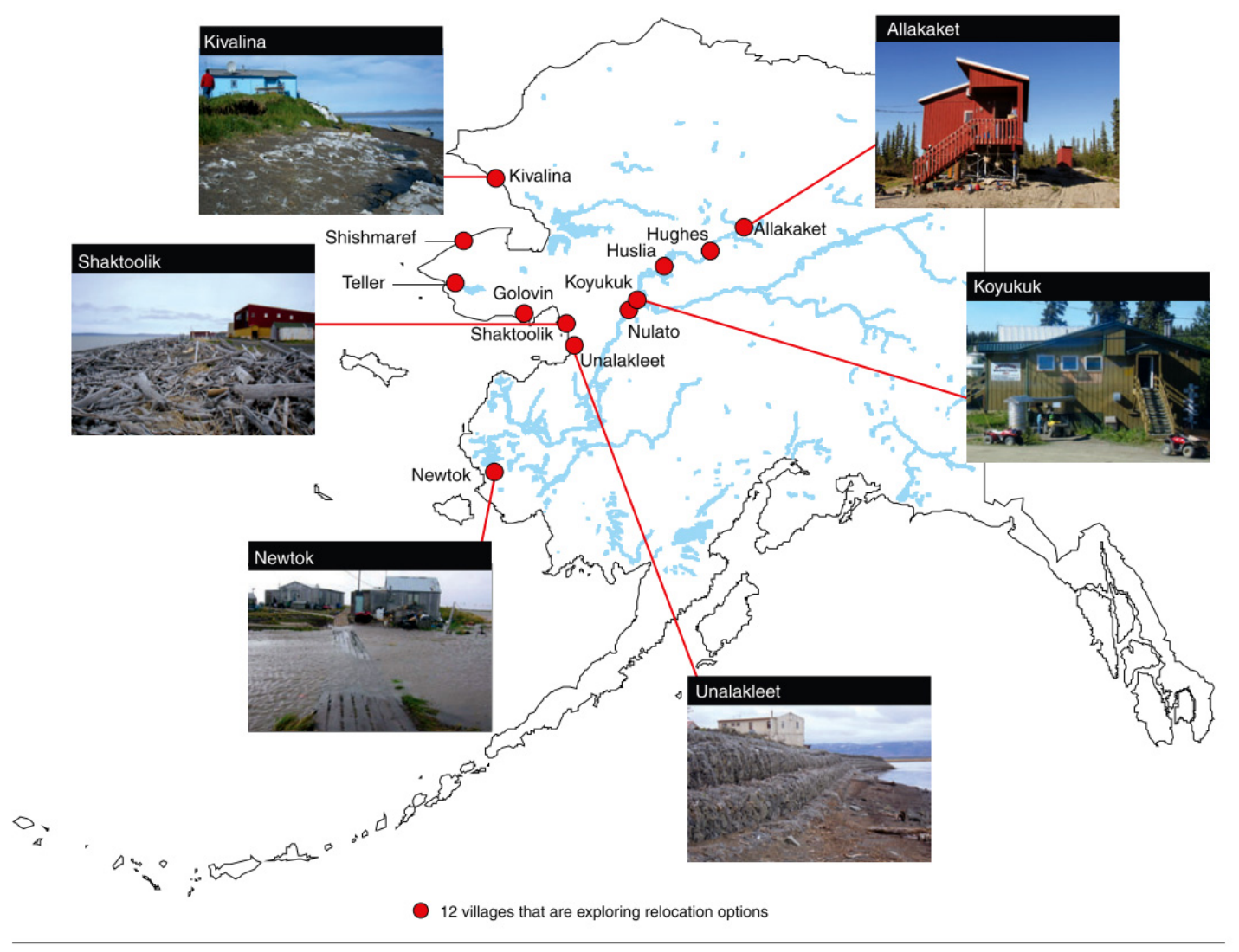

Sources: GAO (analysis); Pitney Bowes Business Insight (map).

infrastructure, and livelihoods. Flood hazards are high because the developed areas of Quinhagak are adjacent to the floodplain of the Kanektok River. Because of its close proximity to the Bering Sea, Quinhagak is also exposed to storm surges (City of Quinhagak Mitigation Planning Team 2012, Powtec 2012).

Critical community infrastructure affected by these hazards includes the only functional dock in the community, the health clinic, and the sewage lagoon (City of Quinhagak Mitigation Planning Team 2012, Powtec 2012). The HIA found that the structural failure of the health clinic was imminent and that erosion threatened the viability of continued use of Quinhagak City Dock (Powtec 2012).

In addition, vessels have difficulty navigating the channels leading to the dock because of silt and large tidal action (Powtec 2012). Fuel barges have been stuck and are often damaged (Powtec 2012). As a consequence, fuel sometimes must be flown into the community at high expense. Coastal Villages Seafood moved its fish processing plant, which employed approximately 100 local people, from Quinhagak because boats were unable to access the plant (Powtec 2012).

Despite the importance of the dock to the community, a report commissioned by the U.S. Army Corps of Engineers and the Denali Commission found that "[r]outine or repeat maintenance dredging is not practical under the Commission's funding parameters" (Powtec 2012:25). The HIA recommends that funding be made available to study a new site location for the community dock.

In addition, coastal erosion affects the new sewage lagoon ( $\mathrm{J}$. Pleasant, personal observation, Increased coastal erosion due to storm activity, https://www.flickr.com/photos/leoalaska/10335743433). The community has a housing crisis, with one-third of the homes in the community unfit for human habitation due to significant subsidence and the infiltration of mold. Erosion threatens approximately 22 people in five residences and 20 essential fish camps. The report found that two of the five residences could be lost within one to five years if not moved or replaced (Powtec 2012).

The HIA recommends monitoring rates of environmental change such as sea level rise and erosion to reduce the cost of repairing and replacing infrastructure and to address the critical need for data to better predict rates of climate-induced environmental change (Powtec 2012). However, no mechanism was left in place to facilitate this monitoring, and no financial or technical assistance resources were provided to assist community residents with this process. Difficult decisions need to be made regarding whether protection in place is a viable long-term strategy to protect community residents from the threats caused by climate change. The combination of antiquated and damaged infrastructure needing replacement or repair, coupled with the 
unknown projected erosion and flooding risk, elucidates the need to implement and design a community-based social-ecological monitoring and assessment tool.

Based on the ACCIMP legislation, Quinhagak is eligible for additional adaptation funding, so it is possible that these funds could be used for monitoring and assessment. However, with limited funding and many critical adaptation needs, it is uncertain whether this funding will be used for monitoring and assessment.

\section{RELOCATION INSTITUTIONAL FRAMEWORK}

An adaptive governance relocation framework would incorporate all of the institutional mechanisms to protect people in the places where they live and also create new mechanisms to implement a relocation process so that national, state, local, and tribal governments can dynamically shift their efforts from protection in place to managed retreat and community relocation (Bronen 2011, Bronen and Chapin 2013).

Implementing an adaptive governance relocation framework requires multi-level and diverse governmental and nongovernmental actors to engage in a collaborative process of knowledge production and problem solving (Kofinas 2009). Adaptive capacity, an essential element of adaptive governance, is the ability to respond to social-ecological disturbances and maintain resilience when responding to rapid ecological change (Armitage and Plummer 2010). Adaptive capacity in social systems refers to the ability of institutions to balance power among interest groups and engage in an iterative learning process that can generate knowledge and be flexible in solving problems. Networks of multiple and diverse organizations are critical for building adaptive capacity (Berkes 2009, Armitage and Plummer 2010).

A community-based social-ecological monitoring and assessment process, designed with local populations and technical experts, can be an essential component of this adaptive governance framework because of the potential to build adaptive capacity and collaboration between diverse institutions. Objective assessment of a hazard, the social perception of that hazard, and the ability to anticipate the sociological effects of ongoing environmental changes are critical to the development of sustainable adaptation strategies (Correa 2011). To integrate the concept of collaboration into conventional risk management, those most directly affected by the hazard must actively participate in the gathering of data during the risk assessment process (May and Plummer 2011).

Local populations document their experiences with the changing climate, particularly extreme weather events, in many different ways. This self-generated knowledge can uncover existing capacity and shortcomings within the community (IPCC 2012). Understanding the rate of climate-induced environmental change is also essential for individuals, communities, and governments to adapt. People need to believe that they cannot be protected in situ and that relocation is not implemented for discriminatory reasons or as a pretext to allow the land on which they live to be used for a different purpose such as commercial development. If people perceive the threat to their lives and livelihoods as high by staying where they are, they may be more likely to consider relocation (Ferris 2012). They also need to have resources to recreate lives and livelihoods in a new location. The political decision-making process also becomes more viable if people believe that relocation is the best adaptation option to provide long-term protection (Correa 2011).

Community-based integrated assessments can foster empowerment, promote human rights protections, and encourage transparent decision-making processes, all of which are elements of good governance (Alfredsson 2013). Human rights principles, based on the fundamental freedoms inherent in human dignity, can be an important foundation on which adaptation strategies are designed and implemented (Moyn 2010, Bronen 2011, Tanner et al. 2015). The right to self-determination is the most important human rights principle to guide climate change adaptation. In the context of climate-induced environmental change that threatens the habitability of the places where people live, self-determination means that people have the right to make decisions regarding adaptation strategies (Bronen 2011, 2014). The right to selfdetermination also means that people have the right to make fundamental decisions about when, how, where, and if relocation occurs to protect them from climate-induced environmental threats. To operationalize this right, people need the capacity to assess and document the environmental changes and sociological effects and vulnerabilities caused by climate change (May and Plummer 2011). However, the ability of this community-based process to foster human rights will depend on the capacity of governance institutions to collaborate, be transparent in decisionmaking, and be inclusive of all sectors of society.

Community-based adaptation also requires information about local-level environmental change. Global, regional, and national climate change assessments generally aggregate information above the level of resolution required for effective community policy (IPCC 2012). Local landscape change can influence microclimate conditions and outweigh the influence of larger geospatial analyses of long-term climate change predictions (Sallenger et al. 2012). For example, at local and regional levels, sea level rise varies and may exceed average global projections, depending on topography and geological factors (Sallenger et al. 2012). Local-level decision makers need to understand how their locality will be affected by global and regional projections of climate-induced environmental change and need to have the governance tools to identify the best policy options to adapt.

Designing and implementing adaptation strategies also require the involvement of multi-level institutions. Community-based integrated social-ecological assessments can facilitate communication between community residents and local, state, regional, and national actors who can bring technical expertise that may not exist at the local level to better assess and implement adaptation strategies. Local knowledge can provide not only a long-term historical perspective, but an understanding of the connections between people and the environment, while Western scientific approaches can generate projections of future change in the context of broader global scientific data analysis (Kannen and Forbes 2011). Through this collaborative data-gathering process, local scenarios can be integrated into regional or national models of climate change scenarios (Lewis 2012). In this way, both residents and government agencies can anticipate vulnerability to implement a dynamic and locally informed institutional response.

In addition, vulnerability to climate change is dynamic, varying across temporal and spatial scales, and depends on economic, 
social, geographic, demographic, cultural, and governance factors (IPCC 2012). Consistent monitoring of environmental change and the effects of these changes on individuals, households, and the larger community offers the opportunity to capture the dynamic nature of a community's vulnerability and resilience to the changes.

Finally, these assessments can also be used as tools to determine whether and when relocation needs to occur. Social and ecological indicators can be used to assess vulnerability and guide the transition from protection in place to community relocation. Unlike government-mandated relocation programs in which the government makes the decisions regarding the timing of relocation, climate-induced relocations require a dynamic process closely connected with changes in the environment that affect the well-being of community residents.

The November 2014 report from President Obama's Task Force on Climate Preparedness and Resilience included a list of recommendations that support funding community-based initiatives that are climate smart and address future climate impacts (White House 2014). The FEMA Disaster Mitigation grant programs and the National Oceanic and Atmospheric Administration (NOAA) climate resilience grant programs could be sources of funding for this community-based process. The PreDisaster Mitigation Program provides funds for hazard mitigation planning and implementation of mitigation projects (GAO 2009). NOAA provides funds to raise public awareness about climate risks and to implement adaptation strategies.

In addition, the creation of an adaptive governance framework that coordinates the efforts of multi-level government agencies to shift from protection in place to relocation would allow for already existing funding to be used more efficiently and strategically. Funding traditionally available to repair and rebuild in the place of a disaster could be allocated to facilitate relocation. Capital funding often available for communities to repair and maintain public infrastructure could be used at a relocation site instead of at a location already deemed vulnerable to future climate risks.

\section{COMPONENTS OF AN INTEGRATED SOCIAL- ECOLOGICAL ASSESSMENT AND MONITORING TOOL}

An integrated social-ecological assessment and monitoring tool has the potential to incorporate the components of a HIA and also to include a health and livelihoods component to the assessment. Environmental changes to be included in the assessment tool include, but are not limited to, rates of erosion and sea level rise, as well as frequency of extreme weather events.

Community residents can learn how to measure erosion rates by using simple mathematical equations, describe the area affected by erosion, and identify the cause of erosion such as wave energy or wind (State of Alaska 2013). In this way, residents will be able to explain erosion using terms familiar to technical experts who can assist with designing and implementing solutions.

Monitoring the health effects of climate-induced environmental change is also critical. Alaska residents describe a variety of climate change effects on health, including morbidity and mortality caused by unpredictable and extreme weather, mental health, changes to lifestyle, and damage to water and sanitation infrastructure (Brubaker et al. 2011). Similar to the monitoring of environmental change, preventing negative health outcomes requires a local-scale understanding of the type, timing, and rate of change, as well as the direct and indirect health effects (Brubaker et al. 2011). Integrated health assessments can systematically identify and quantify the many pathways through which climate change can affect health in different social and ecological contexts. The World Health Organization suggests that a natural point of entry for health impact assessments is during the planning process for climate-induced relocations because the assessment can put the key health issues in front of the policy makers who directly influence the implementation of plans (Winkler et al. 2013).

Finally, the integrated assessment should incorporate a component that focuses on the environmental effects on livelihoods, which would include the availability of subsistence foods. A community-based monitoring and assessment tool that integrates climate change impacts on infrastructure, health, and livelihoods has the potential to address holistically the way that climate change affects the lives and livelihoods of community residents, facilitate adaptation, and dynamically address ongoing environmental change. Use of this tool in Quinhagak could assist the community in evaluating the feasibility of maintaining infrastructure such as the community dock, assessing the effects of environmental change on subsistence livelihoods as well as the cash economy, and determining the most appropriate long-term adaptation strategy.

\section{CONCLUSION}

The combination of extreme weather events and slow, ongoing environmental change will challenge the capacity of people and the governance institutions charged with protecting them. Preventive relocations provide an institutional mechanism to protect people proactively, before the land on which they live and maintain livelihoods is no longer habitable or ceases to exist. However, no governance framework in the United States currently addresses the essential issues of deciding when a preventive relocation should occur and who should make the decision that relocation is warranted. Government-mandated relocations have impoverished relocated populations and caused the rupture of kinship ties and social networks. New governance institutions need to be designed and implemented so that the adverse effects of relocation are minimized or avoided. Community-based integrated social-ecological assessments, which create multi-level multi-disciplinary knowledge production with local communities leading the data gathering effort, can be a critical component of this new governance framework.

Responses to this article can be read online at: http://www.ecologyandsociety.org/issues/responses. $\mathrm{php} / 7801$

\section{Acknowledgments:}

This research was supported by National Science Foundation grant "IGERT: Global-Local Interactions: Resilience and Adaption of Social-Ecological Systems in a Rapidly Changing North" (Grant \#0654441). I am also grateful to NOAA grant Resilient Alaska 
Native Coastal Communities: Integrated Social-ecological Monitoring and Assessment Supporting Adaptation Decisions for funding to design and implement this community-based monitoring and assessment tool.

\section{LITERATURE CITED}

Alfredsson, G. 2013. Good governance in the Arctic. Pages 185-198 in N. Loukacheva, editor. Polar law textbook II. Norden, Nordic Council of Ministries, Copenhagen, Denmark.

Armitage, D., and R. Plummer. 2010. Adapting and transforming: governance for navigating change. Pages 287-302 in D. Armitage and R. Plummer, editors. Adaptive capacity and environmental governance. Springer, Berlin, Germany. http://dx.doi. org/10.1007/978-3-642-12194-4 14

Berkes, F. 2009. Evolution of co-management: role of knowledge generation, bridging organizations and social learning. Journal of Environmental Management 90(5):1692-1702. http://dx.doi. org/10.1016/j.jenvman.2008.12.001

Bronen, R. 2011. Climate-induced community relocations: creating an adaptive governance framework based in human rights doctrine. N.Y.U Review of Law and Social Change 35 (2):101-148.

Bronen, R. 2014. Community relocations: the Arctic and South Pacific. Pages 221-242 in S. F. Martin, S. Weerasinghe, and A. Taylor, editors. Humanitarian crises and migration: causes, consequences and responses. Routledge, New York, New York, USA.

Bronen, R., and F. S. Chapin III. 2013. Adaptive governance and institutional strategies for climate-induced community relocations in Alaska. Proceedings of the National Academy of Sciences 110 (23):9320-9325. http://dx.doi.org/10.1073/pnas. 1210508110

Brubaker, M. Y., J. N. Bell, J. E. Berner, and J. A. Warren. 2011. Climate change health assessment: a novel approach for Alaska Native communities. International Journal of Circumpolar Health 70(3):266-273. [online] URL: http://www.circumpolarhealthjournal. net/index.php/ijch/article/download/17820/20301.

City of Quinhagak Mitigation Planning Team. 2012. City of Quinhagak hazard mitigation plan. City of Quinhagak, Quinhagak, Alaska, USA. [online] URL: https://www.commerce. alaska.gov/web/Portals/4/pub/Quinhagak $\% 20-\% 20 J a n \% 202012$.pdf.

Correa, E. 2011. Resettlement as a disaster risk reduction measure: case studies. Pages 19-24 in E. Correa, editor. Preventive resettlement of populations at risk of disaster: experiences from Latin America. International Bank for Reconstruction and Development, World Bank, Washington, D.C., USA. [online] URL: http://www.gfdrr.org/sites/gfdrr/files/publication/ preventive resettlement_LAC experiencesDS150.pdf.

Esterberg, K. G. 2002. Qualitative methods in social research. McGraw-Hill, New York, New York, USA.

Ferris, E. 2012. Protection and planned relocations in the context of climate change. United Nations High Commission of Refugees, Division of International Protection, Geneva, Switzerland. [online] URL: http://www.unhcr.org/5024d5169.html.
GAO [Government Accountability Office]. 2003. Alaska Native villages: most are affected by flooding and erosion, but few qualify for federal assistance. Government Accountability Office, Washington, D.C., USA. [online] URL: http://www.gao.gov/new. items/d04142.pdf.

GAO [Government Accountability Office]. 2009. Alaska Native villages: limited progress has been made on relocating villages threatened by flooding and erosion. Government Accountability Office, Washington, D.C., USA. [online] URL: http://www.gao. gov/new.items/d09551.pdf.

Grannis, J. 2011. Adaptation tool kit: sea-level rise and coastal land use. Georgetown Climate Center, Washington, D.C., USA. [online] URL: http://www.georgetownclimate.org/sites/www. georgetownclimate.org/files/Adaptation Tool Kit SLR.pdf.

ICISS [International Commission on Intervention and State Sovereignty]. 2001. The responsibility to protect. International Development Research Centre, Ottawa, Canada. [online] URL: http://responsibilitytoprotect.org/ICISS\%20Report.pdf.

IPCC [Intergovernmental Panel on Climate Change]. 2012. Summary for policymakers. Pages 3-21 in C. B. Field, V. Barros, T. F. Stocker, D. Qin, D. J. Dokken, K. L. Ebi, M. D. Mastrandrea, K. J. Mach, G.-K. Plattner, S. K. Allen, M. Tignor, and P. M. Midgley, editors. Managing the risks of extreme events and disasters to advance climate change adaptation. Cambridge University Press, Cambridge, UK. [online] URL: https://www. ipcc.ch/pdf/special-reports/srex/SREX_Full_Report.pdf.

Jha, A. K. 2010. Safer homes, stronger communities: a handbook for reconstructing after natural disasters. Global Facility for Disaster Reduction and Recovery, World Bank, Washington, D. C., USA. [online] ULR: https://www.gfdrr.org/sites/gfdrr/files/ publication/SaferHomesStrongerCommunitites.pdf.

Joughin, I., B. E. Smith, and B. Medley. 2014. Marine ice sheet collapse potentially under way for the Thwaites Glacier basin, West Antarctica. Science 344:735-738. http://dx.doi.org/10.1126/ science. 1249055

Kälin, W. 2011. A human rights-based approach to building resilience to natural disasters. Brookings Institution, Washington, D.C., USA. [online] URL: http://www.brookings.edu/research/ papers/2011/06/06-disasters-human-rights-kaelin.

Kannen, A., and D. L. Forbes. 2011. Integrated assessment and response to Arctic coastal change. Pages 79-122 in V. Rachold, D. Forbes, H. Kremer, H. Lantuit, and L.-O. Reiersen, editors. State of the Arctic coast 2010: scientific review and outlook. HelmholtzZentrum, Geesthacht, Germany. [online] URL: http://library. arcticportal.org/1277/1/state of the arctic coast 2010.pdf.

Kofinas, G. P. 2009. Adaptive co-management in social-ecological governance. Pages 77-101 in F. S. Chapin III, G. P. Kofinas, and C. Folke, editors. Principles of ecosystem stewardship: resiliencebased natural resource management in a changing world. Springer, New York, New York, USA. http://dx.doi.org/10.1007/978-0-387-73033-2 4

Lewis, D. A. 2012. The relocation of development from coastal hazards through publicly funded acquisition programs: examples and lessons from the Gulf Coast. Sea Grant Law and Policy Journal 5(1):98-139. [online] URL: http://nsglc.olemiss.edu/ SGLPJ/vol5No1/Lewis.pdf. 
May, B., and R. Plummer. 2011. Accommodating the challenges of climate change adaptation and governance in conventional risk management: adaptive collaborative risk management (ACRM). Ecology and Society 16(1): 47. [online] URL: http://www. ecologyandsociety.org/vol16/iss1/art47/.

Mobley, C. 2012. World War II Aleut relocation camps in southeast Alaska. National Park Service, Anchorage, Alaska, USA. [online] URL: http://www.nps.gov/aleu/learn/historyculture/upload/mobleyaleut-book-lo res.pdf.

Moyn, S. 2010. The last utopia: human rights in history. Harvard University Press, Cambridge, Massachusetts, USA.

Nicholls, R. J., and A. Cazenave. 2010. Sea-level rise and its impact on coastal zones. Science 328:1517-1520. http://dx.doi. org/10.1126/science. 1185782

Nichols, S. S., and C. Bruch. 2008. New frameworks for managing dynamic coasts: legal and policy tools for adapting U.S. coastal zone management to climate change. Sea Grant Law and Policy Journal 1(1):19-42. [online] URL: http://nsglc.olemiss.edu/ SGLPJ/Vol1No1/2Nichols.pdf.

Powtec. 2012. Qinhagak hazard impact assessment. Powtec, Bremerton, Washington, USA. [online] URL: https://www. commerce.alaska.gov/web/Portals/4/pub/Quinhagak $\% 20$ HIA $\% 20$ Main $\%$ 20Report FINAL\%20112112.pdf.

Raleigh, C., and L. Jordan. 2010. Climate change and migration: emerging patterns in the developing world. Pages 103-131 in R. Mearns and A. Norton, editors. Social dimensions of climate change: equity and vulnerability in a warming world. International Bank for Reconstruction and Development, World Bank, Washington, D.C., USA.

Sallenger, A. H. Jr., K. S. Doran, and P. A. Howd. 2012. Hotspot of accelerated sea-level rise on the Atlantic coast of North America. Nature Climate Change 2:884-888. http://dx.doi. org/10.1038/nclimate1597

Siders, A. 2013. Managed coastal retreat: a legal handbook on shifting development away from vulnerable areas. Columbia Public Law Research Paper 14-365. Columbia University, New York, New York, USA. http://dx.doi.org/10.2139/ssrn.2349461

State of Alaska. 2013. Understanding and evaluating erosion problems. Alaska Department of Commerce, Community, and Economic Development, Anchorage, Alaska. [online] URL: https://www.commerce.alaska.gov/web/Portals/4/pub/ Understanding\&EvaluatingErosionPub.pdf.

Tanner, T., D. Lewis, D. Wrathall, R. Bronen, N. Cradock-Henry, S. Huq, C. Lawless, R. Nawrotzki, V. Prasad, M. A. Rahman, R. Alaniz, K. King, K. McNamara, M. Nadiruzzaman, S. HenlyShepard, and F. Thomalla. 2015. Livelihood resilience in the face of climate change Nature Climate Change 5:23-26. http://dx.doi. org/10.1038/nclimate2431

Tester, F. J., and P. Kulchyski. 1994. Tammarniit (mistakes): Inuit relocation in the eastern Arctic, 1939-63. UBC Press, Vancouver, Canada.

Thomas, A. 2014. Philippines: typhoon survivors face obstacles to recovery. Refugees International, Washington, D.C., USA. [online] URL: http://www.refworld.org/docid/53884f464.html.
USACE [U.S. Army Corps of Engineers]. 2006. Alaska village erosion technical assistance program: an examination of erosion issues in the communities of Bethel, Dillingham, Kaktovik, Kivalina, Newtok, Shishmaref, and Unalakleet. U.S. Army Corps of Engineers, Anchorage, Alaska, USA. [online] URL: http:// www.housemajority.org/coms/cli/AVETA_Report.pdf.

USACE [U.S. Army Corps of Engineers]. 2009. Alaska baseline erosion assessment: study findings and technical report. U.S. Army Corps of Engineers, Anchorage, Alaska, USA. [online] URL: http://climatechange.alaska.gov/docs/iaw USACE erosion rpt.pdf.

White House. 2014. President's state, local and tribal leader's task force on climate preparedness and resilience: recommendations to the President. White House, Washington, D.C., USA. [online] URL: https://www.whitehouse.gov/sites/default/files/docs/ task force report 0.pdf.

Winkler, M. S., G. R. Krieger, M. J. Divall, G. Cissé, M. Wielga, B. H. Singer, M. Tanner, and J. Utzinger. 2013. Untapped potential of health impact assessment. Bulletin of the World Health Organization 91(4):298-305. http://dx.doi.org/10.2471/ blt. 12.112318 